\title{
Religion, Memory, and Materiality: Exploring the Origins and Legacies of Sectarianism in the North of Ireland
}

\author{
Audrey Horning (D
}

Accepted: 29 January 2020 / Published online: 2 August 2021

(C) The Author(s) 2021

\begin{abstract}
The early 17th-century Plantation of Ulster, in which the English Crown sought to plant loyal British colonists in the north of Ireland, is commonly understood as overtly religious in intent and action, and is viewed as the foundation for today's divide between Protestant and Catholic communities in Northern Ireland. Archaeological and documentary evidence complicates this straightforward narrative by demonstrating considerable cultural exchange and the emergence of hybrid practicessuggesting that, during the plantation period itself, religion may have been less influential than economic and political pragmatism. By the end of the 17th century, however, religion took on a more prominent political and cultural role, overtly materialized in objects, settlement patterns, and landscapes. The nature and timing for this transition is examined through archaeological case studies and considered in light of contemporary historical memories regarding the plantation and the origins of sectarianism in Ireland.
\end{abstract}

Resumen La plantación de Ulster de principios del siglo XVII, en la que la Corona inglesa buscó colocar colonos británicos leales en el norte de Irlanda, se entiende comúnmente como abiertamente religiosa en intención y acción, y se considera la base de la división actual entre las

\footnotetext{
A. Horning $(\bowtie)$

Department of Anthropology, William and Mary, Williamsburg, VA 23185, U.S.A.

e-mail: ajhorn@wm.edu

A. Horning

Queen's University Belfast School of Natural and Built

Environment, Belfast, UK
}

comunidades protestantes y católicas en Irlanda del Norte. La evidencia arqueológica y documental complica esta narrativa sencilla al demostrar un considerable intercambio cultural y el surgimiento de prácticas híbridas, lo que sugiere que, durante el período de la plantación, la religión puede haber tenido menos influencia que el pragmatismo económico y político. Sin embargo, a fines del siglo XVII, la religión asumió un papel político y cultural más prominente, materializado abiertamente en objetos, patrones de asentamiento y paisajes. La naturaleza y el momento de esta transición se examinan a través de estudios de casos arqueológicos y se consideran a la luz de las memorias históricas contemporáneas sobre la plantación y los orígenes del sectarismo en Irlanda.

Résumé La Plantation d'Ulster au début du 17ème siècle, au sein de laquelle la Couronne anglaise a entrepris d'implanter des colons britanniques loyaux dans le nord de l'Irlande, est habituellement considérée comme ouvertement religieuse dans ses intentions et ses actions. Elle est vue comme le fondement de la division actuelle entre les communautés protestante et catholique en Irlande du Nord. Les preuves archéologiques et documentaires viennent compliquer cette narration simpliste en démontrant un échange culturel considérable et l'émergence de pratiques hybrides - suggérant que, durant la période de la plantation elle-même, la religion ait pu exercer une moindre influence par rapport au pragmatisme économique et politique. Cependant, au terme du 17ème siècle, la religion a joué un rôle politique et culturel plus dominant, matérialisé de manière évidente dans les objets, les modèles d'implantion et les paysages. La nature et la 
temporalité de cette transition sont examinées dans le cadre d'études de cas archéologiques et envisagées à la lumière de mémoires historiques contemporaines relatives à la plantation et aux origines du sectarisme en Irlande.

Keywords Northern Ireland · sectarianism · religion · conflict $\cdot$ colonialism

\section{Introduction}

The 30-year conflict in Northern Ireland, known as the "Troubles" (1968-1998), is commonly understood as a sectarian religious conflict between Protestant and Roman Catholic communities with roots stretching back to the 17th-century Ulster Plantation. The plantation was (at least on parchment) an overtly colonial effort to subdue the largely Catholic, Gaelic population through the importation of loyal, mainly Protestant, English and Scottish settlers. Conflict analysts (e.g., McGarry and O'Leary [2000]) and common historical narratives present the ongoing division between today's two broadly drawn oppositional communities, Catholic, Nationalist, Republican vs. Protestant, Unionist, Loyalist, as a direct outcome of the plantation and efforts to impose the Reformation in Ireland. While there is no doubt that ethnoreligious identity was at core of the 20th-century Troubles, evidence from the 16th and early 17th centuries, explored below, is rather more equivocal. To move forward in any meaningful way as a post-conflict society requires reconsidering the origins of sectarianism, reassessing the meaning and role of religion in early modern Ireland, and putting to the test the assumption that 20th-century conflicts were the inevitable outcome of those of the early 17 th century.

\section{Background}

In the wake of the Protestant Reformation and Henry VIII's break with Rome in 1534, England attempted to assert firmer political control over Ireland as part of the Tudor kingdom's competition with Spain. Ireland, as a Catholic country, was viewed (with good reason) as a potential backdoor for a Spanish invasion of England. The intensification of English involvement began with efforts to impose the Reformation through the dissolution and seizure of monasteries and the outlawing (on paper) of Catholic religious practice (Gillespie 1997). In 1539 and 1540, suppression was materialized through the destruction of devotional figures, including the Raphoe Crucifix, Kilmore Madonna, Ballybogan Crucifix, a figure of St. Catherine in Downpatrick, and possibly Our Lady of Trim, a statue believed to perform miracles (Cochran Anderson 2012:141). Religious icons continued to be a target, as indicated by a 1550 act that required the destruction of every image "of stone, tymbre, allebasta or earthe, graven, carved or paynted, whiche heretofore have bene taken out of anye churche or chappell or yet stande in anye churche or chappell" (Moss 2011). In reality, most iconoclasm was focused in an area within or near the "Pale," the fortified area encircling Dublin that was under the influence of the Crown. Beyond the Pale, less than $10 \%$ of monastic houses (unless on Crown lands) experienced dissolution in the 1530s and 1540s (Bradshaw 1974:207).

Unlike in England, where dissolution activities prompted violent protests, opposition in the Pale was relatively muted. Brendan Scott (2005) has explained this lack of overt protest as a strategic response on the part of Gaelic and Old English (descendants of 12thcentury Anglo-Norman invaders) elites, who were "unwilling to anger the Crown" particularly as some profited from access to newly available lands as well as financial compensation. This instrumental approach to politico-religious change does not imply any fundamental change in adherence to Catholic beliefs or practices, but instead signals the same pragmatism that led many Irish elites to surrender their lands to the Crown in exchange for an English title and re-grant of properties. Such individualistic actions reflect the fact that Ireland was not a unified nation, but rather one in which political power was held by hereditary chieftains or lords who maintained influence through control of inherited territories and a complicated system of mutual obligation. Recognizing the on-the-ground negotiations around the Reformation challenges presumptions about the origins of sectarianism, as summarized by Alan Ford (2005:5): "[T] he casual assumption that sectarianism began with the reformation and lived unhappily ever after has not stood up to closer historical association." While the Reformation clearly did have significant impacts, those impacts were often localized and primarily concentrated in the eastern reaches of the island.

These uneven efforts to impose the Reformation in Ireland were then followed by the first effort at plantation as a means of exerting political control. This took place in the Irish Midlands in the 1550s and was a shortlived reconfiguring of settlement that was reliant upon 
local elites, including Catholic Old English and Gaelic Irish, rather than on any critical mass of incomers (Loeber 1991). The failure to effect political change across the island precipitated the next phase of the English campaign, which included episodes of brutal warfare. The suppression of one rebellion, led by the Old English Earl of Desmond, allowed the English to confiscate over half a million acres of land in the province of Munster and earmark those lands for plantation. Plans for the Munster Plantation were far more rigid than those previously employed in the Midlands and included efforts to allocate uniform parcels of land to English planters (MacCarthy-Morrogh 1986). While some gains were made in terms of new development, the existence of the Munster Plantation was cut short by a more protracted period of warfare known as the Nine Years' War (1503-1603), which ultimately ended in the defeat of Irish forces and the final surrender of Ulster leader Hugh O’Neill (O’Neill 2017). The Kingdom of Ireland then became subordinate to the English Crown under James I (James VI of Scotland), albeit retaining a separate government in Dublin.

To what extent could the warfare of the 16th century be interpreted as religious in nature? One lasting historical narrative has emphasized ethnoreligious conflict, exemplified by the scorched-earth policy implemented by English forces, materialized through the targeting of houses of worship, as lamented by the Gaelic commentator Philip O’Sullivan Beare:

They entered and profaned the churches, turning them into stables and to profane uses. They fiercely destroyed images of the saints and in the height of their delight went on not doubting but that with so strong an army they would on this single expedition crush O'Neill and all the Catholics and cow their resolution. (Byrne 1903:90-91)

While the English forces certainly did occupy and damage ecclesiastical structures, so too did the Irish. Paul Logue (2016) has reexamined the uses of sacred buildings in the Nine Years' War in some considerable detail, and he observes that, in actuality, some of the damage caused at Armagh Cathedral was conducted by Gaelic forces, such as the careful removal of the church tower to prevent its use as a lookout by the English. One of the many other examples he provides of Gaelic deployment of ecclesiastical sites is that of Ardboe, County Tyrone (Fig. 1), where Gaelic forces under Hugh O’Neill erected an up-to-date fortification surrounding the medieval church and its High Cross. Highlighting these actions is not to excuse the damage wrought by English forces, but merely to recognize that ecclesiastical sites were tactically valuable to both sides, regardless of how the sacred nature of these locales was understood.

In the wake of the defeat of the Irish in Kinsale and in an effort to retain control of Ireland, the northernmost province of the island, Ulster, was singled out for particular attention by the English Crown. Ulster had remained the most Gaelic part of the island, but now was to be subdued through the radical redrawing of boundaries and the distribution of lands to so-called undertakers, including English and Scots planters, servitors (former military men), the Anglican church, and a small number of native landholders. Of the nine counties of the province of Ulster, only counties Antrim and Down were excluded from this colonial scheme, principally because individual landholders had already begun enacting their own plantation ventures. The most radical element of the official Ulster Plantation scheme saw the seizure of the former lordship of the O'Cahan clan and the granting of the territory to the "London Companies" - the merchant guilds of the city of London whose considerable cash resources were coveted by the king (Moody 1939; Curl 1986). The companies were extremely reticent to become involved in Ulster while they had more lucrative projects underway in other colonial zones, but they could not realistically oppose the Crown. Having reluctantly agreed to spearhead the Londonderry Plantation in the newly established County Londonderry, the companies were required to follow an extremely restrictive set of guidelines that included removing all Irish - a requirement not made of any other undertakers - alongside the building of 25 new towns, including expanding the urban ports of Coleraine and Derry (renamed Londonderry), and establishing new settlements (Horning 2013:244-270; Tracey and Horning 2019). Plantation as a whole was supposed to be about identity transformation, but only the unidirectional sort, with the Irish becoming "civilized" through adopting and internalizing English ways of being, including the expectation that Catholics convert to Protestantism.

\section{Planters and Protestantism}

Examination of documentary and material sources suggests that, while conversion to Protestantism was 
Fig. 1 Earthworks from a 16thcentury Irish fortification in Ardboe churchyard, County Tyrone. (Photo by author, 2018.)

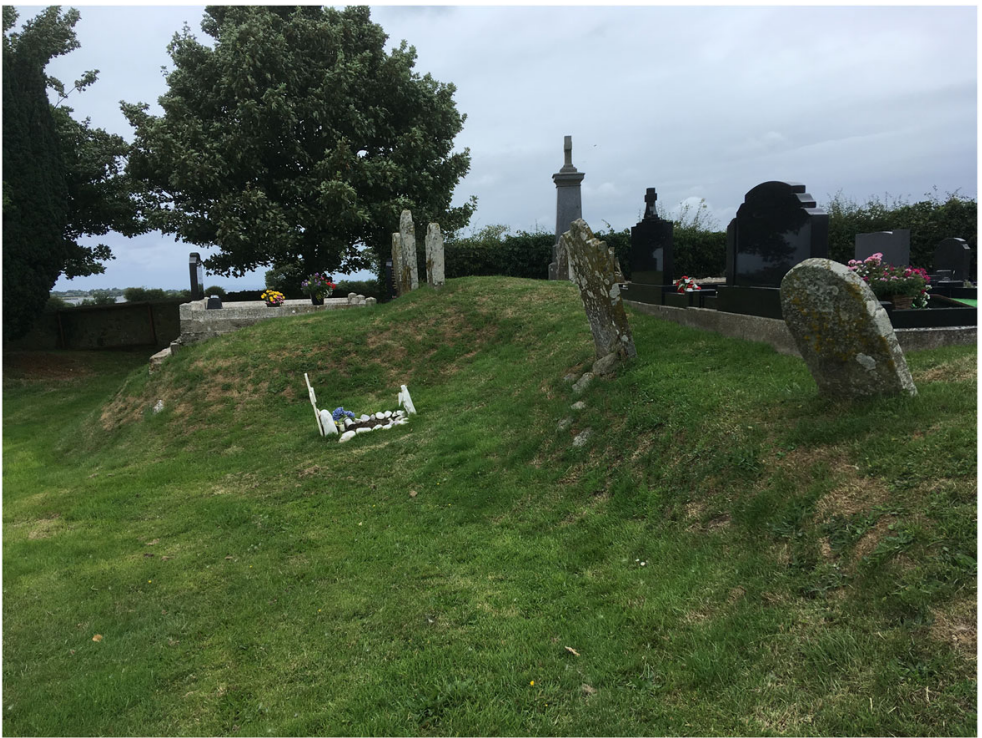

intended to be a fundamental element of plantation throughout the island of Ireland, other factors outweighed the religious proselytization. Self-evidently, efforts to convert the whole of the island to Protestantism were unsuccessful, given the continuing dominance of the Catholic faith on the island. Here a more specific focus on Ulster becomes particularly relevant to considerations of the Troubles. Six of the historical nine counties of Ulster would ultimately become Northern Ireland, remaining within the United Kingdom when the island was partitioned in 1921 and distinguished by the political dominance of a Protestant elite. But the outcome of the 20th-century movement for Irish independence from Britain and the role played by religion in that conflict was not predetermined, nor would it have been self-evident in the 17th century. Implementation of the plantation process was slow and often haphazard. The attractions of Ulster for an aspirational settler population, or even for committed evangelists, were minimal, given the high expectations of plantation doctrine and the limited economic development of the region. Largely rural and lacking infrastructure in the wake of warfare, famine, and pestilence, the chief attractions of Ulster lay in basic commodities, such as cattle, timber, salmon, and eels, and the land itself (Horning 2018). From the start, plantation efforts in the north of the island struggled to attract a critical mass of settlers. Those who did journey to the province were not always the best equipped to effect significant change.

Insight into the character and activities of Protestant missionaries is provided by an early 17 th-century description penned by the Scottish traveler and chronicler William Lithgow (1974:252-253): "The alehouse is their Church, the Irish Priests their Consorts ... their Text Spanish Sacke, their Prayers carousing, their singing of Psalmes the whiffing of tobacco, their last blessing Aqua vitae, and all their doctrine, sound drunkennesse."

Furthermore, according to Lithgow (1974:379), the Protestant minister "defrayeth all charges for the Priest," and the pair assiduously avoid doctrinal dispute: "their conference onely pleading forbearance; the Minister affrayed of the Priests Wood-Carnes [woodkernes were Irish fighters], and the Priests as fearefull of the Ministers apprehending or denoting them." While Lithgow's account is clearly hyperbolic and part of a long tradition of unsympathetic British descriptions of Ireland, the state of mutual forbearance combined with a clear willingness to fraternize that he describes accords with other evidence - historical and archaeological - from the Ulster Plantation. Significant daily interactions between natives and newcomers are evident in hybrid material culture, shared settlements, and documentary accounts of the commonality of multicultural drinking spaces such as that enjoyed by Lithgow's minister and priest (Horning 2009, 2013; Tracey and Horning 2019).

In practice, planters were by necessity pragmatic in their execution of plantation regulations. Even more crucially, and in clear violation of the intents of plantation, some prominent planters were themselves Catholic rather than Protestant; one most notable example being the Catholic Highland Scot Randall Arranach MacDonnell, who held a seat at Dunluce Castle on the 
north County Antrim coast (Breen 2012a). MacDonnell, who had fought against the English with the Irish during the Nine Years' War, curried sufficient favor with James I to not only retain lands in north Antrim on the eve of plantation, but to significantly augment them with further grants of land. There he brought in both Protestant and Catholic settlers to a new town he built at Dunluce. In a nod to plantation expectations, he and his son, Randal Óg, and Randal Óg's English Catholic wife Katharine oversaw the building of a new Protestant church in the ruins of a medieval church. In naming it St. Cuthbert's after the Northumbrian saint, the MacDonnells were overtly indexing Englishness. While ostensibly doing his duty by plantation religious precepts, Randal Arranach was not so secretly funneling money to the Scottish Franciscans and the Jesuits to advance the Counter Reformation (MacCuarta 2016). Furthermore, he ensured that the nearby friary of Bonamargy (Fig. 2) was reedified, updated for Catholic worship, and granted over to the Franciscans (Breen 2012b). The increasing role of the Franciscans in north Antrim was part of a significant expansion of their activities on the island of Ireland. One estimate from 1618 placed their numbers at 160 ; by 1644 , that number had increased to at least 1,000 (Cochran Anderson 2012:149).

MacDonnell made no effort to hide his Catholicism, maintaining a private chapel for Catholic worship within Dunluce Castle and openly worshiping at Bonamargy, where he was buried following his death in 1636 . While
MacDonnell was singular within the elite stratum of plantation Ulster for his active involvement in the Counter Reformation, elsewhere on the island prominent individuals also made material efforts to support it. In 1620s Dublin, for example, seven different Catholic religious orders were established (or reestablished), reliant upon Irish patronage (Loeber and StouthamerLoeber 2006:245). The Jesuits received a considerable boost from the patronage of Elizabeth, Countess of Kildare, constructing a chapel and college named "Kildare Hall" with her finance. Remarkably, Kildare Hall was located "a three minute walk from Dublin Castle" (Loeber and Stouthamer-Loeber 2006:247), the seat of English authority in Ireland.

While MacDonnell was unusual for his extensive encouragement of the Franciscans, he was far from the only prominent Catholic planter in Ulster. The Hamilton earls of Abercorn, Scottish planters in County Tyrone, routinely opened their homes in and around the plantation town of Strabane for Catholic worship, while principally attracting Scottish Catholic tenants to their lands (Lennon 2019:165). Their overt actions went largely uncircumscribed, insofar as they were the wealthiest settlers in the region; see Roulston (2019:90). In 1629, the bishop of Derry, George Downham, sent a somewhat equivocal letter of protest to Claud Hamilton:

I hear that, though your father was given land in Strabane in order to maintain the reformed religion, the place is become the sink into which all
Fig. 2 Bonamargy Friary. (Photo by author, 2018.)

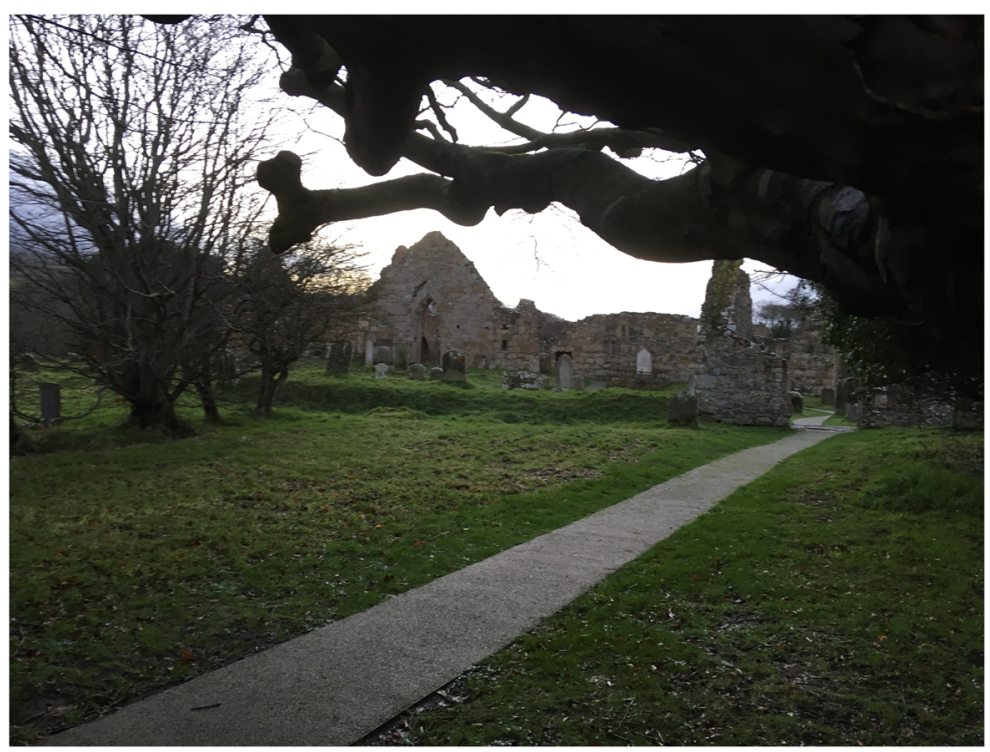


the corrupt humours purged out of Scotland are run. Idolatrous Popish masses are daily celebrated. As your Church is heretical and your Pope an antiChrist, I think it my duty to oppose you, but, before appealing to higher authorities, I write to ask you to come and see me in order that I may convince you that you are in the wrong. (Mahaffy 1900:511)

Clearly the bishop was not pleased with what was happening behind closed doors in Strabane, but, at the same time, his letter exposes his personal inability to impose any change directly or to mete out any punishment. The letter reads more as an exhortation to talk about the issue in private, with the likeliest intended outcome merely to encourage Hamilton to be less obvious about his activities, and, in fact, that is precisely what he exhorted Hamilton to do: "[I]f he would not embrace the reformed religion, that he should keep his own religion to himself and not ... pervert others" (Mahaffy 1900:511). The known Catholicism of the Hamiltons only became an issue in 1629 , when the bishop wrote his letter, because of the centrality of religion in the Anglo-Spanish War (Hunter 2011:44).

The Hamiltons were not alone in supporting Catholic worship within County Tyrone. Mervin Touchet, an English recusant, oversaw the residence of numerous Catholics on his grant near Omagh (MacCuarta 2016:148), while, back in Strabane, James Ferrell, a merchant, invited priests into his home where they officiated Mass for dozens of worshippers (Lennon 2019:162). While the Strabane masshouses were intended primarily for incoming Scottish Catholic planters, elsewhere it is clear that English and Scottish Catholics also welcomed Irish Catholics. For example, the English Catholic Brownlow family of Armagh brought Catholic Irish tenants to their lands and employed a clever strategy of intermarriage with Gaelic elites in order to cement and protect their Irish land claims (Clendenning 2004). The Brownlows relocated to Ulster from Nottinghamshire, where they (ostensibly) were practicing Anglicans, suggesting they viewed their move to Ulster as an opportunity to practice openly as Catholics. While this was certainly not the intention of plantation theorists, it does reflect the character of anti-Catholic measures within England. As argued by the historian David Edwards (2005), Ireland was actually an attractive destination for English recusants fleeing harsher punishment than was common in Ireland, where Catholicism continued to be the dominant religion.
As he notes: "[T]he anti-Catholic measures adopted by the [Anglo] Dublin government were mild in comparison to those that were taken up in England" (Edwards 2005:105). Concern over the persecution of English recusants was also a factor in the transatlantic activities of another prominent Catholic planter, Lord Baltimore. In addition to manors in counties Longford and Wexford, Baltimore's family, the Calverts, established settlements in Newfoundland and Maryland (Lyttleton 2017). Given the uneven acceptance of Reformation ideology within England, it is more than reasonable to expect that its influence was not wholesale amongst the planter population in Ireland. While the Calverts or MacDonnells or Hamiltons possessed sufficient political and economic clout to be overt in their religious activities, how many other planters continued to adhere more secretly to the beliefs with which they had been raised?

There were, of course, many planters who were overtly committed to the reformed religion. One of those was Richard Boyle, who rose from relative obscurity to become the wealthiest individual in all three kingdoms of Ireland, Scotland, and England (Heffernan 2015). In 1602, Boyle, born in England, acquired 42,000 ac. of land in the Munster Plantation and ultimately added another 58,000 ac. Boyle, who became Earl of Cork in 1620 , has been traditionally viewed as a committed Protestant, commended by Charles I for having erected "severall churches, townes, castles and other buildings," and introducing "true religion ... civility and government" (Heffernan 2018:43). The king, however, turned a blind eye to the reality that Boyle was reliant on a largely Irish tenantry, especially in Gaelic-dominated West Cork, where Boyle chose not to interfere in religious practices. In a recent reassessment of Boyle's actions, historian David Heffernan notes that "just as profit superseded any consideration for establishing an ethnically English plantation, so too it appears to have trumped any desire to foster an exclusively Protestant estate" (Heffernan 2018:61). Boyle may have consciously deflected attention from his tacit permission for Catholicism through his investment in five ornate funerary monuments commemorating himself and his family (Tait 2001). In Heffernan's (2018:62) view: "These were monuments designed, not with the greater goal of advancing the godly in early Stuart Ireland, but as testament to the dynasty Boyle founded." Political and economic power lay at the heart of Boyle's success and of his ultimate legacy. 
Other planters worked harder to support and promote Protestantism. Demonstrating the integral nature of Reformation and plantation, the Anglican bishop of Kilmore, William Bedell, was given the job of laying out a new plantation town in County Cavan called "Virginia." Notably, Bedell learned Irish and worked with two Irishmen, Muircheartach Ó Cionga (Murtagh King) and Séamus de Nógla (James Nangle) to translate the Old Testament into Irish, although the manuscript would not be published until 1685, 43 years after Bedell's death (Scott 2012). Bedell was clearly unusual in his scholarship and his desire to convert the Irish, insofar as he was a lone voice in recognizing the necessity of communicating in the Irish language, as acerbically observed by an early 20th-century biographer (Lindsay 1914:232): "Bedell found that none of his clergy, being Englishmen, knew Irish, while very few of their flocks knew anything else - a state of things absolutely fatal to the exercise of any influence, religious or otherwise." While a number of Irish Catholic clergy had converted in the late 16th and early 17th centuries, and were therefore capable of preaching the new religion in the Irish tongue, few efforts were made to support their increase.

\section{The Anglican Church and Plantation}

At an institutional level, the extent to which the established church was fully committed to the conversion of Irish natives is placed in doubt by a review of documentary and archaeological evidence. What few churches were built or reedified, for example, were chiefly situated in locales to serve the incoming planters, although a number were intentionally sited on high ground to symbolize (if not actualize) Protestant hegemony (Cherry 2019:33-34). When medieval churches were reused by the Anglican church, the primary alterations focused upon the removal of altars, sculpture, and partitions (rood screens) that served to separate the celebrant from the congregation (Lyttleton 2008:88). But the numbers converted are low, as opposed to churches that were simply stripped and abandoned. Evidence from plantation-period County Offaly indicates a remarkable lack of any activity to build or convert churches. James Lyttleton (2008) examined 66 medieval church sites in County Offaly, of which only 17 had any trace of activity taking place in the years between 1550 and 1700. Eighteenth-century Anglican use of these churches is indicated by building alterations, armorial plaques, and commemorative devices, but those features are absent for the century and a half previous, when these sites were ostensibly converted from Catholic to Protestant worship. As Catholic worship became relegated to the home or to nondescript "masshouses," medieval church buildings that were not adapted for Protestant worship were simply abandoned (Cotter 2006).

Church buildings provide a tangible material link to the experience of worship and a hint as to the importance of the church in daily life. And, here again, a problem is encountered even in the Ulster Plantation. The official Protestant Church of Ireland routinely commandeered preexisting medieval churches, but seldom invested much in their restoration or upkeep. Where churches in the Ulster Plantation did receive investment, it was more often than not from private individuals, such as Sir Richard Hansard (Armstrong 2019:171), who helped fund the church in Lifford (and where he is commemorated with an elaborate funerary monument), or Sir Arthur Chichester, who supported the construction of Dungannon's church. It is difficult not to agree with the conclusion of historian Brendan Scott $(2013: 58)$ that the ruinous condition of most churches in the Ulster Plantation was an "indication of how little investment lay people were willing to make in their local churches." Even the Irish Society (representing the 12 premier London companies) failed to prioritize church construction in the Londonderry Plantation. While the plantation was launched in 1609 , Londonderry still lacked a church in 1622. According to a commission sent to assess progress, the Irish Society "should have begun with a church, which the city wants, having not any other than a piece of an old monastery," referring to a disestablished Augustinian house (Russell and Prendergast 1880:367). In 1624, the Privy Council ordered the Irish Society to "erect a fit church for the inhabitants" (Russell and Prendergast 1880:528), suggesting that little had changed. That the Irish Society failed to erect a suitable church in Londonderry did not prevent them from castigating the individual London companies in 1620 for their churches being "very backward and unready whereby the ministers take ground of excuse for their own neglect of their calling" (Moody 1939:190). The upshot was that plantation churches barely served the existing small Protestant population, let alone facilitated any widespread conversion of Catholics. 
The quality of clergy who found themselves charged with spreading the gospel in Ulster was often questionable, as observed by Lithgow and implied by the Irish Society. Some, according to Alan Ford (2005), milked the system, accused of exacting both English tithes as well as traditional Irish duties. These underpaid, poorly educated Protestant ministers competed with the more organized efforts of Jesuit and Franciscan missionaries, who could count upon wealthy patrons. When Randal Arranach MacDonnell admitted harboring a priest in 1621, that priest was a Scottish Jesuit, Father Patrick Anderson, who had been making the rounds of Ulster's Scottish elites, including the Protestant James Hamilton in his castle at Killyleagh. The only reason MacDonnell was "outed" was because his accuser, a disgruntled neighbor, was entitled to half the fine imposed upon the earl (MacCuarta 2016:148-149).

But elites like MacDonnell operated under a different set of rules than did the London Companies. Clearly, company lands would not be places where evidence of Catholic practices would be found. Or would they? In 1632, English servitor Sir Thomas Phillips complained that "[t]here are many beneficed priests in the Plantation." Backing up his complaint with evidence, he then listed 24 names and the fees those individuals charged for their services, including marriages, christenings, "extreme unction," burials, and "churning butter." Furthermore, according to Phillips, "there are also vagrant friars who wander about and live on the country" (names also supplied) and, even more remarkably, seven of the London Companies (Ironmongers, Salters, Drapers, Vintners, Fishmongers, Grocers, and Skinners) had permitted masshouses to be erected on their lands (Mahaffy 1900:643-644). While Phillips does not mention masshouses on the other company lands, it is probable that unofficial masshouses were in operation in areas long associated with worship practices, including holy wells and holy trees, as well as field altars and religious buildings.

\section{Materiality of Religious Beliefs}

What can be said about the materiality of religious beliefs in this fraught period in Irish history? That is a difficult question to answer, given the likely disconnect between official doctrine (be it imposed Protestant or retained Catholic) and the universe of folk beliefs, many of which were shared across the Irish Sea (Tarlow
2011). At an elite level, one could point to those new churches that were constructed or to material culture, such as the elaborate silver chalices in the cathedral at Londonderry (Fig. 3). Inscribed with the arms of the Irish Society, these communion chalices were intended to materialize the intended link between Protestantism and plantation. That parishioners of all faiths were required to contribute to the purchase of such finery further demonstrates the political rather than purely religious potency of these objects, as underscored in the 1619 report of the Dominican friar Richard Bermingham (Fray Ricardo de la Peña) to the Spanish king Philip III: "[T]he Protestants have broken up the stone altars that were in our churches," and, in addition to this indignity, Catholic parishioners were required "to contribute towards defraying the cost of altering the churches and of providing a wooden table and two silver cups for what they call communion" (Walsh 1917:51). Yet Protestant churches were not the only institutions commissioning silver plate. As noted above, the Counter Reformation supported the establishment of new places of worship and learning. These institutions also became consumers of plate, statuary, and elaborate vestments, some of which survive to be studied. And older devotional objects still retained their potency, with many surviving the early depredations of the Reformation through being kept hidden by elite families (Cochran Anderson 2012).

What of more ordinary and portable Catholic items, such as religious medals and crucifixes? Pretty rare finds on the whole, but insofar as numerous examples have been found in what was also supposed to be an exclusive Protestant colonial venture, Jamestown, Virginia (Parno 2006), the seeming lack in Ulster could just as easily be explained in terms of the comparative dearth of archaeological investigations in Ulster, as well as the very different circumstances of life. Unlike the traumatized, starving settlers of early Jamestown, planters in Ulster were not reduced to eating one another nor dumping the earthly goods of their deceased compatriots into wells and other holes in the ground. Portable devotional items certainly circulated in Ireland. For example, a 1623 procession of fragments, purported to be of the True Cross, from High Cross Abbey to the urban center of Kilkenny attracted considerable numbers of English Catholic pilgrims, who "purchased as many medals, images and bottles of holy water from the nearby shrine of Monahincha as they could carry back to England" (Edwards 2005:108). Elite families also maintained, in 
Fig. 3 Irish Society chalices in St. Columb's Cathedral, Londonderry. (Photo by author, 2013.)

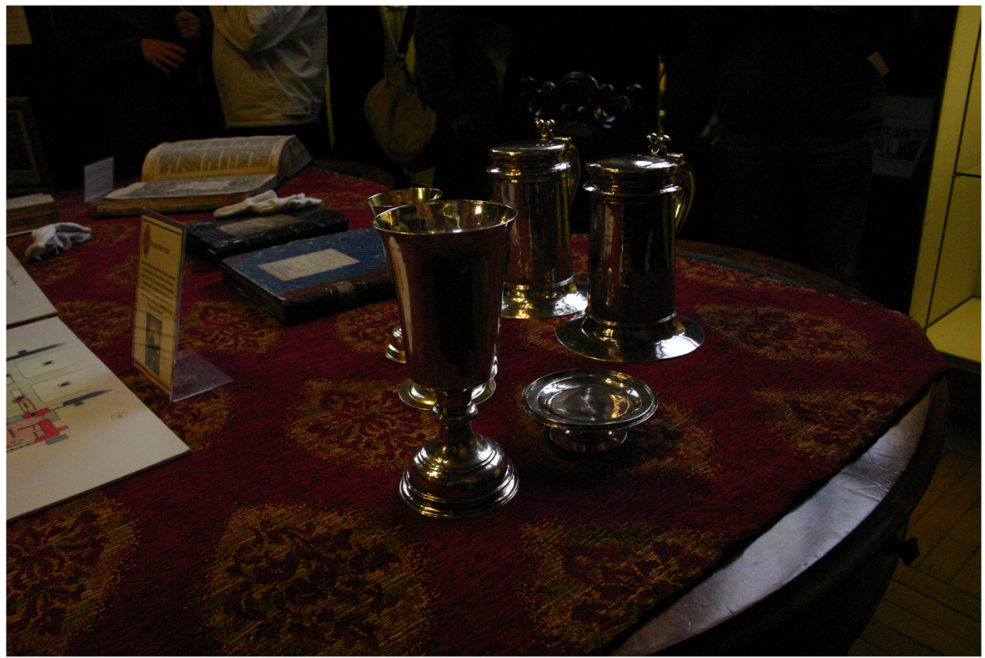

private, devotional items, such as reliquaries and statuary. A 1584 report of the temporary capture of Dunluce Castle from the MacDonnells by English forces under Sir John Perrot recorded the seizure of "Holy Columkill's Cross," presumably a reliquary containing a cross associated with St. Columba (MacDonnell 1992:109). One can also safely assume that, as in England, Dissolution activities accelerated the circulation of relics and their increasing appearance in domestic contexts (Walsham 2010). Another find from Jamestown, a small silver reliquary found in association with the remains of the settler Gabriel Archer, further highlights the increasingly personal ownership of items that were once exclusive to ecclesiastical settings (Allison 2016). Colm Donnelly (2005) has also noted a continuation of the medieval practice of including devotional representations on the fabric of elite dwellings. Such representations took the form of wall paintings, drawings, and carvings. Donnelly highlights the particular significance of carving of the IHS monogram, associated with the Society of Jesus (Jesuits), on a number of mid-17th-century structures in County Limerick, within the revived Munster Plantation.

One can also chart the continued use of Catholic places of pilgrimage as part of annual ritual rounds. One of the best examples is Struell Wells, County Down (Fig. 4), a holy well site where St. Patrick reportedly spent time in contemplation, and where pilgrimages began at least as early as the 12th century (McCormick 2009). Seventeenthcentury references pinpoint the continued, active use of Struell even in the midst of the upheavals wrought by warfare and plantation. So well known was the site that even the English military commander Sir Richard Moryson, who had seized and occupied an Irish tower house in nearby Downpatrick, took his houseguests to visit, as noted by one visitor, Josias Bodley. While the bulk of Bodley's 1602 account focused upon Moryson's lavish hospitality, Bodley recalled one pleasant day out riding on Moryson's "handsome steeds": "We quickly mount; we visit the Well and Chair of St. Patrick" (Bodley 1904:340-341). Bodley tells us no more of what they did on their visit, but his silence is compelling. Did they pray, immerse themselves in the waters of the wells, or content themselves with laughing at the locals while not daring to disturb the sanctity of the site? A 1640s account of Struell recorded that "there are seldom to this day, less than three or four hundred persons here upon Midsummer Eve, yearly to wash and drink, and say their Pater Nosters" (Dobbs [1873] in McCormick [2009:54] and Hill [1873:383]). Such large gatherings were hardly likely to go unnoticed and, as such, must be understood as tacitly, and perhaps overtly, condoned. Struell represents just one of many Irish sites of enduring ritual that often transcend confessional allegiances.

Other sites of enduring ritual include burial grounds, with mortuary practices an obvious source of evidence for interrogating personal and communal religious beliefs. Considerable attention has been paid to continuities in the use of cilliní, segregated unconsecrated burial grounds for unbaptized children, throughout Irelandsee, e.g., S. Donnelly et al. (1999), C. Donnelly and Murphy (2008), and Tarlow (2011:46-47)—while development-driven excavations of churchyards have also uncovered significant assemblages of human 
Fig. 4. Complex of bath buildings at Struell Wells. (Photo by author, 2015.)

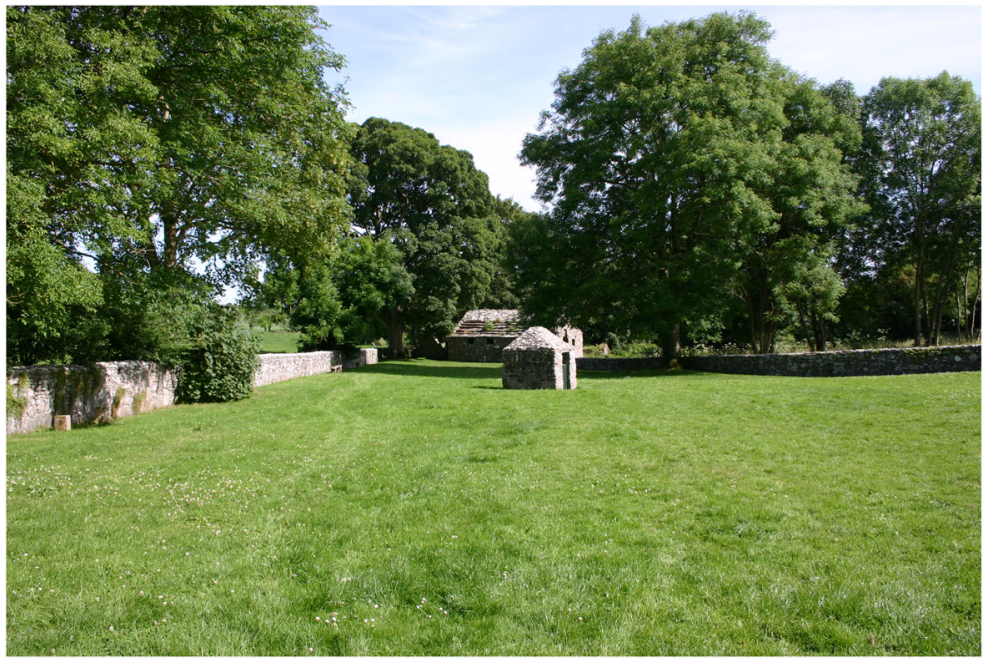

remains. The most extensive published project examining a graveyard associated with a Gaelic population occurred at Ballyhanna, County Donegal (McKenzie and Murphy 2018). A total of 1,296 individual burials, dating between the 7th century and the early decades of the 17th century, were recorded and removed to make way for a new bridge. Subsequent osteological analysis focused upon assessing health for the population in aggregate across the nine centuries that the burial ground was in use. Chronological imprecision makes it difficult to pinpoint any significant changes to mortuary practices that may have been precipitated by plantation, although the relative uniformity of the burials may suggest little disruption to traditional burial practice. Outside the deliberate placement of quartz crystals, a practice found throughout northwestern Europe, items found within the burials were principally related to the manner of burial, i.e., shroud pins and coffin nails. Only one individual was clearly buried with a rosary, but radiocarbon dating of her remains provided an unhelpful date range of 1499-1791 (McKenzie and Murphy 2018:44). However, given that the burial ground ceased to be used by the third decade of the 17th century, the date of the burial can be refined to the 16th to early 17 th centuries and, as such, could conceivably reflect a shift in practice to including more overtly Catholic material culture.

An excavation in St. Elizabeth's Church in Dundonald, County Down, yielded a much smallerscale glimpse into 17 th-century mortuary practices ( R. Logue and Gormley 2007). At the behest of the presentday Church of Ireland, an excavation was conducted within the footprint of a church that was erected in
1634, near the location of an abandoned medieval parish church. Fifty-five articulated burials were uncovered, most predating the 1634 Protestant church. However, two children were buried with coins dating to the $1640 \mathrm{~s}$ placed in their hands, suggesting that Protestant doctrine was overlooked in favor of continuing a common folk practice with roots as far back as the 12th century. While no firm conclusions can or should be drawn from this one site, it would not be surprising to see that Catholic and Protestant dead were treated in similar ways, steeped in deeper Western European tradition. Furthermore, as observed by Clodagh Tait (2005:20), even when churches were converted to Protestant houses of worship, their churchyards continued to be used by Catholics: "[O]ne of the fascinating features of interdenominational relations in early modern Ireland is the continued burial of Catholics in churches that had been taken over by the Church of Ireland, and the erection within them of monuments to Catholics." On other occasions, Catholic bodies in churches and churchyards transferred to Protestant control were removed and reinterred in family vaults or mortuary houses (Tait 2002:88).

Fortunately, the deceased do not always have to be disturbed to allow the investigation of changing mortuary practices. The 17 th century witnessed a considerable increase in the erection of aboveground memorials to commemorate the dead. For Ulster, both McCormick (2007) and Mytum $(2006,2009)$ have observed that the practice of erecting decorated dated tombstones was influenced by practice in Scotland. Such commemorative strategies, however, were not solely the preserve of incoming Scots planters, be they Protestant or Catholic. 
The gentry of all backgrounds participated in the erection of commemorative markers, which were as much about family claims to place and space as they were memorials to a particular individual (Tait 2002). As observed by McCormick (2007), while privatized plots and grave markers were an outcome of the Reformation, native Irish elites adopted these practices because they provided a visual representation of attachment and claim to place. While heraldry and mortality symbols dominate on both Catholic and Protestant grave markers in the 17th century (Fig. 5), others overtly indicate confessional identity, such as the IHS symbol and its Counter Reformation associations (C. Donnelly 2005).

\section{Transformation of Ecclesiastical Sites}

A range of fates befell ecclesiastical sites in Ulster, most commonly the abandonment and dereliction recorded

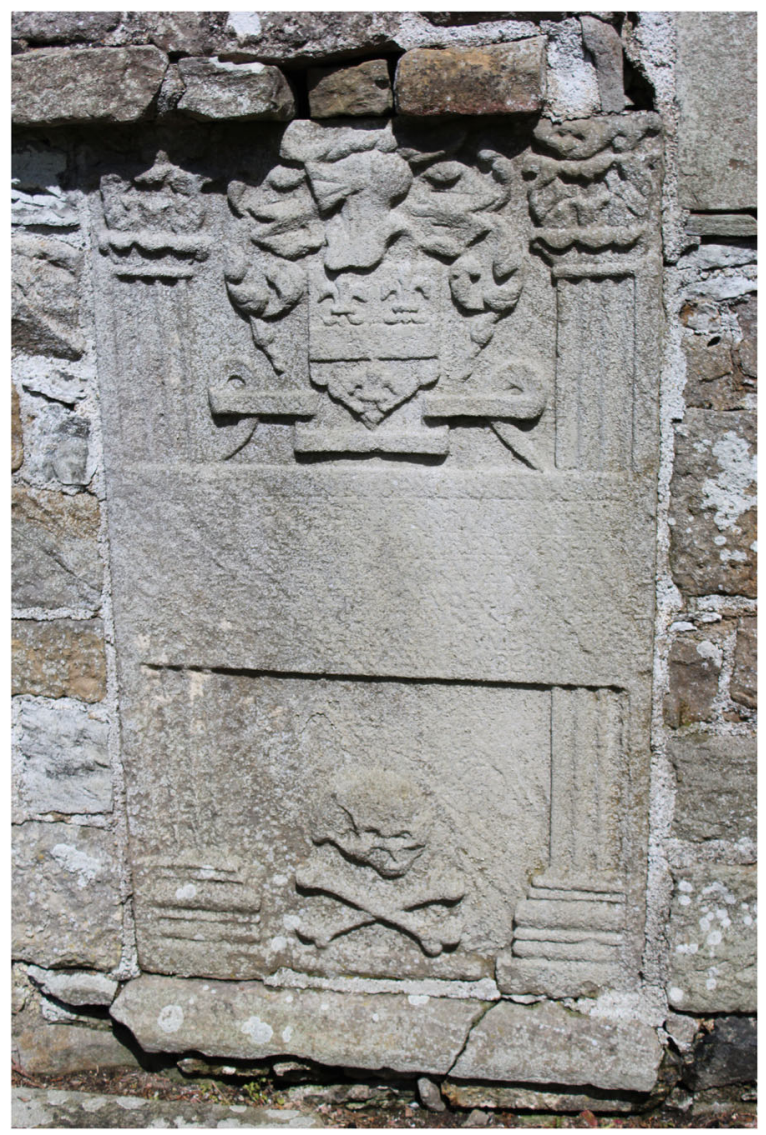

Fig. 5. Seventeenth-century marker at Aghalurcher, County Tyrone, featuring heraldry and mortality symbols. (Photo by author, 2015.) for Dundonald. Others were repurposed for secular uses. At Dungiven, on the Skinners' Company lands in the Londonderry Plantation, Sir Edward Doddington, military servitor and agent for the company, redeveloped an Augustinian priory (Brannon and Blades 1980; Brannon 1985). Dungiven was a significant site within the O'Cahan Lordship, as the O'Cahans served as patrons for the priory and had also constructed a tower house at the site. Doddington, as agent, was responsible for building a manor house and bawn (fortified enclosure) from which to discharge his duties. In transforming the former O'Cahan stronghold, Doddington focused his energies on the tower house, reedifying it and building his manor house immediately adjacent. The church itself was to be used for Protestant worship, and its conversion is reflected in the addition of an early 17th-century porch entry on the north wall of the long axis of the church.

Here the story gets more interesting. Once entering the nave and proceeding to the east, a visitor or worshiper is able to pass into a 13th-century chancel. Still extant inside that chancel is a remarkable canopied effigy tomb (Fig. 6). Erected probably in the late 15th century to commemorate a mercenary O'Cahan (the effigy is clad in the garb of a Highland warrior), in the early 17 th century the tomb would certainly have been understood as a clearly Gaelic object and, by extension, a Catholic object. Iconographic representations were frequently the target of Protestant reformers, whether deemed secular or sacred. In 1610, the Protestant bishop of Raphoe, Scotsman Andrew Knox, forced his servants to remove a statue of the Virgin Mary from a parish church on the Ironmongers' lands near Agivey on the River Bann and had it taken to the Irish Society's settlement at Coleraine, where it was publicly destroyed by fire in the center of the settlement (Armstrong 2019:167). It is salutary to consider the audience for this event and its response. Ostensibly, Coleraine was a planter town for planters, but, like all other settlements, was reliant upon the Irish. Burning the statue in the center of the town, presumably in the Diamond (marketplace), would have been extremely provocative and doubtless (and intentionally) upsetting for any Catholic witnesses, as well for all those who shared a worldview in which significant powers were commonly ascribed to sacred objects.

Doddington's decision to retain the O'Cahan effigy tomb at Dungiven must be viewed as a deliberate decision, perhaps in deference to (or a desire to associate 


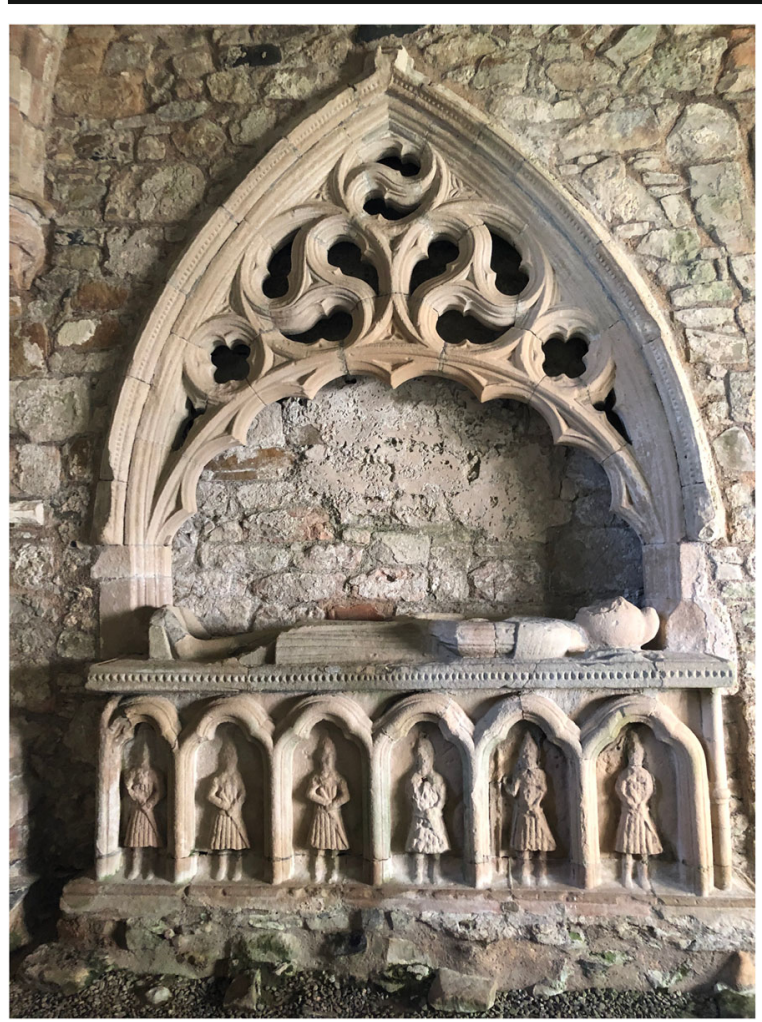

Fig. 6 Dungiven effigy tomb. (Photo by author, 2019.)

with) the status of the O'Cahans, as well as a pragmatic response to the demographics on the Skinners' estate. The Skinners failed to attract many incoming settlers, no doubt because they drew the worst lot when the lands for the Londonderry Plantation were divided. Straddling the Sperrin Mountains, their 49,000 ac. lacked ready access to cultivable lands, was wholly landlocked, and was interspersed with native and church lands (Curl 1986:285-287). A survey of 1622, enumerating men of military age, found a scant 12 British men in residence on the whole of the company's proportion vs. 348 Irish men (Moody 1939:218). The Skinners, unsurprisingly, permitted masshouses and Catholic worship. Give the numerical dominance of the Irish, it is conceivable that the manor-house incumbents turned a blind eye to other visitors to the priory. The entrance to the church was not within the fortified area of the property, and that entrance was also not visible from the manor house, although it might have been from the upper floors of the tower house. Unfortunately, only the foundation of the tower house survives today, so it is not possible to access the positioning of upper-level window openings. But if the intent had been to oversee and protect
Protestant parishioners, one would expect the new entrance to the church to be located within the bawn, not outside it.

Sir Edward Doddington died in 1618, but his wife, Lady Ann Beresford Doddington (later Cooke), remained mostly in residence until her death in the 1670s (Hamlin and Brannon 2003:263). Despite the stark demographics, Lady Ann retained her hold. Her successful strategy was revealed in a 1641 complaint: "Lady Cooke brought in no English, but was a great fosterer of Irish Papists" (Mahaffy 1900:291). The documentary record is silent on the personal beliefs held by Lady Ann and her husband before her. The decision to transform a sacred space into a residence could be easily read as a profane, antiCatholic action, yet it could also reflect a recognition of the power of place, just as the decision to retain elements of the church architecture and its figural sculpture implies some combination of respect, deference, and fear, as much as colonial appropriation.

Whatever the complex reasons underpinning their personal choices, Doddington and Lady Ann were not the only planters to find value in reusing ecclesiastical properties. Doddington's brother-in-law, the servitor Sir Thomas Phillips, acquired the dissolved Dominican friary at Coleraine in 1604 and converted it into a fortified manor house, one that he was then forced to surrender to the Irish Society. Similarly, the Dominican friary in Newtownards, County Down, was first surrendered to the English in 1541 and then granted to an early 17thcentury Scottish planter, Hugh Montgomery. In 1608, Montgomery employed Irish laborers to reroof the church and to repair and reroof the priory walls "for his Lady and children and servants (which were many) to live in" (Hill 1869:61). Montgomery laid further claim to the former ecclesiastical structure through the addition of a grand entrance surrounded by ornate Renaissance carved stonework featuring his own initials (Hamlin and Brannon 2003:256). Irish Lord Deputy Chichester made an even grander gesture when he acquired the former Franciscan friary in the garrison town of Carrickfergus, County Antrim. He demolished the entire complex and replaced it with an opulent mansion once described as possessing "as many windows as there are days in the year; the top is turreted and defended with wall balustrades, the entry is handsome. ... Its staircase is admirable; and its gate or door much more so, on account of the many pieces of sculpture with which it is ornamented" (de Rochefort 1672; McSkimin 1909:156-157). 
The aforementioned bishop of Raphoe, Andrew Knox, himself notably transformed the Carmelite friary at Rathmullan in County Donegal into his own personal home (Fig. 7), much as other wealthy Englishmen grasped ecclesiastical properties recently confiscated and deconsecrated in England (e.g., Willmott and Bryson [2013]). As acknowledged by Sarah Tarlow (2003:115), "much post-medieval reuse of preReformation material should be interpreted as iconic rather than casual because of the potent cultural meanings of ecclesiastical material culture in the 16th and 17th centuries." The politicized nature of religion and religious expressions was widely understood. Rathmullan Friary was not simply a convenient stone building in a convenient location for transport on Lough Foyle: it was symbolic as a Catholic house of worship, but also symbolic for being the iconic place of embarkation for the 1607 "Flight of the Earls," when Ulster's leading Gaelic chiefs set sail for the continent, leaving behind a power vacuum. Unlike the Doddingtons, Knox did not retain any sculptural representations that may once have been within the friary. Through converting the nave and the transept for domestic purposes while retaining the chancel as a private chapel, Knox also ensured that his legacy was obvious for all to see: he placed a stone bearing his initials and the date " 1618 " above the door (Gwynn and Hadcock 1970:291; Lacy 1983:345-347). Knox's plaque was later deliberately effaced, in what must also be understood as a symbolic gesture.

\section{Recalibrating Religion and Division}

To make a long and complicated story succinct, the Ulster Plantation period cannot be understood as the black-and-white, absolute, and oppressive imposition of the Reformation or, indeed, any type of fully formed Protestantism on the defeated Catholic Irish. The intimate linkage of ethnicity and confessional allegiance that would later characterize difference (see discussions in Carey and Lotz-Huemann [2005]) on the island had not yet been entirely forged. So when did religion become much more closely associated with division and ethnic identity? One has to look to the latter half of the 17th century. Thirty-odd years of relative peace, based upon an uneasy accommodation between the numerically dominant Irish and the incoming planters, was shattered by the outbreak of violence in Ulster in 1641 (MacCuarta 1993). Initially a localized movement primarily intended to ensure the rights of property-holding Ulster Gaelic elites, the 1641 Rising/Rebellion soon spread throughout the island. Thus an armed constitutional protest, intended to restore and guarantee the role of Catholic elite in the governance of Ireland as a kingdom, devolved into a more overtly religious conflict as one front in the broader War of Three Kingdoms (Gillespie 1997). English and Scottish Catholics joined Irish compatriots in the Catholic confederacy, initially fighting against the Protestant forces of the Crown. Cromwell's intervention in 1649 accelerated the violence, with Protestants in Ireland dividing their
Fig. 7. Rathmullan Friary and the manor house of Bishop Andrew Knox, Rathmullan, Donegal. (Photo by author, 2019.)

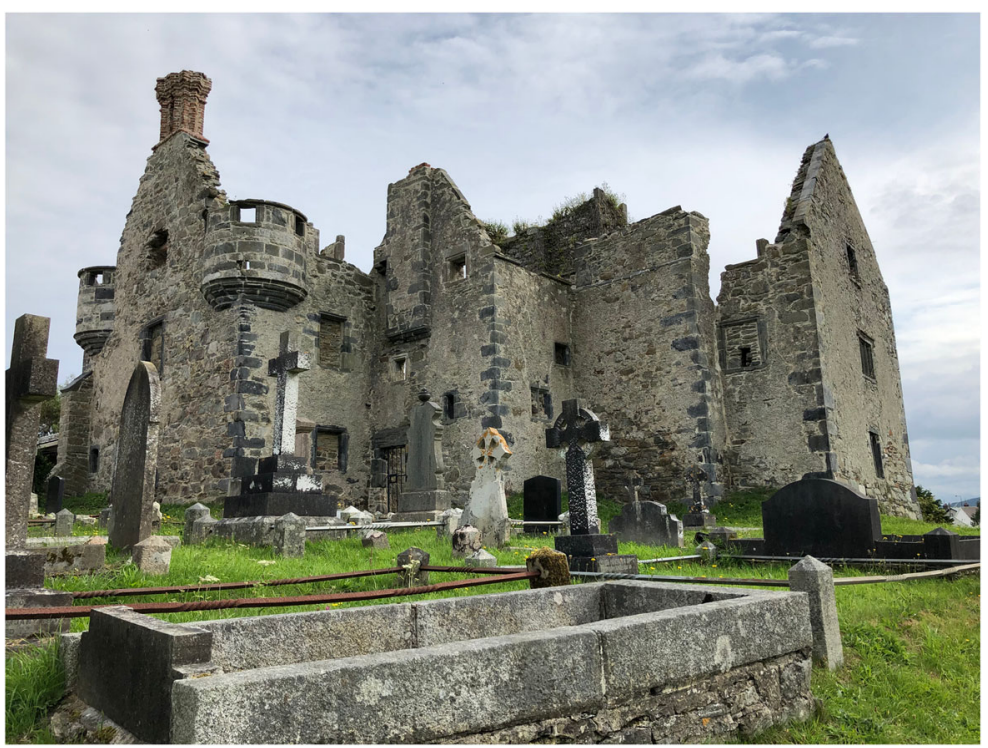


allegiances between the Parliamentarian and Royalist forces, and confederate Catholics compelled to forge an alliance with the exiled Charles II.

The redistribution of landholdings that took place in the aftermath of the warfare, made manifest in the 1652 Act of Settlement, ultimately brought far more radical changes to Irish settlement and society than had the plantations of the first half of the century. To illustrate the scale of the transformation, in 1641, 59\% of land remained in the hands of Catholic landowners; that figure diminished to a mere $22 \%$ by 1688 (Cullen 1974; MacCuarta 1993; Barnard 2004:13,29,61). Under Cromwell, priests were officially declared guilty of treason in 1653 and many were expelled, transplanted, or simply fled, while Catholic practices were banned outright. Incentivized by this transition and the availability of land, significant numbers of settlers made their way to the north of Ireland from Lowland Scotland, shifting the demographics far more effectively than plantation ever had. That said, some antiCatholic proscriptions were loosened during the Restoration, and Catholic worship, even when banished to rural masshouses or mass rocks, continued.

The journal of the Quaker William Penn, son of a Munster planter, provides a description of one such outdoor mass. On 5 December 1669, while traveling to the home of a Penn family tenant, Penn (1952:28) recorded in 1670 that he "passed a great company of Irish gathered to the Mass upon a hill." The relative nonchalance of his observation is indicative of Penn's general toleration for Catholicism, but also reflected the 1667 decree by Lord Orrery (Roger Boyle, son of Richard Boyle), forbidding any Catholic religious services within Cork City, but permitting worship out in the countryside (Dickson 2005:50). Penn recorded another encounter in which he betrayed a rather less tolerant attitude. This was on 10 April, when, on the way to Rosscarbery, he "overtook a burying, barbarous like the heathen" (Penn 1952:48). Penn may have been referring to the caoineadh, the women's lament performed over the dead. Such "keening," as it was anglicized, not only offended many English commentators, but was also opposed by the Catholic Church (Lysaght 1997). While a decree of 1670 implored priests to "bring to an end the wailings and screams of female keeners who accompanied the dead to the graveyard" (O Súilleabháin 1967:138-140), the caoineadh remained a common practice in Ireland until the 20th century, notwithstanding continued condemnation by both the Catholic and Protestant churches.
The decades following Cromwellian warfare and the Restoration were crucial to the entrenchment of patterns of inequality, religious discrimination, and economic control in the hands of a small Protestant majority. But, in 1685, the ascension of the Catholic King James II to the throne was widely seen as threatening Protestant power while concomitantly promising a brighter future for Irish Catholics. Armed conflict inevitably followed and was strongly associated with ethnic/ religious identity in a manner that had not been the case a century previous. Anglican control over Ireland was assured after the Williamite Wars of 1688-1690, with the defeat of the Catholic James II and the accession of the Protestant William of Orange to the throne. The 18th century saw power increasingly consolidated into the hands of a small Anglican elite, with laws enacted that disenfranchised Catholics as well as dissenting Protestants, including Quakers and Presbyterians. Religious discrimination contributed to significant transatlantic migration to the Middle Atlantic region: David Noel Doyle (1981) estimates that over one million Irish Protestants emigrated in the period 1715-1790.

The end of the 18th century saw another armed struggle. Led by the United Irishman, the 1798 rebellion was influenced by both the American and French revolutions and saw Catholics and dissenting Protestants, primarily Presbyterians, come together (ultimately unsuccessfully) to challenge the power of the Anglican Ascendancy and its hold over a stratified economy and society (Connolly 2008). Outside the cities, systems of tenancy had developed that severely constrained the abilities of non-elites to control their own lives. In the wake of continued disenfranchisement, the horrors of the Great Famine, and high levels of emigration, nationalist sentiment coalesced throughout the island in the latter half of the 19th century. At that time, Home Rule efforts were supported by both Catholic and Protestant leaders throughout the island. By the second decade of the 20th century, opposition to Home Rule had become rooted in Ulster and the Unionist cause increasingly regarded as Protestant in nature.

Following a week-long armed rebellion in 1916 and a two-year War of Independence (1919-1921), a treaty was signed in December 1921 creating the Irish Free State, but retaining six counties of Ulster within the United Kingdom. Irish identity in the new state was self-consciously constructed as Celtic, Catholic, and rural (Graham 1994). Emphasis on Gaelic continuity was enshrined within the precepts of the new Irish 
government, with the 1937 constitution stressing adherence to the precepts and faith of the Catholic Church: de facto identifying Irishness with Catholicism. In Northern Ireland, the Unionist majority held political power and institutional discrimination was rife. In 1968, demands for greater civil rights by an expanding Catholic population tipped over into violence. The Provisional Irish Republican Army (PIRA/IRA) employed violence first to defend its communities and then in fighting geared toward unification and the removal of British forces, opposed by Loyalist paramilitaries. Over the course of the next 30 years, intermittent violence took the lives of over 3,500 and injured more than 50,000 (Sutton 2001) in a land with a population of only around 1.4 million. Levels of street violence were high, and everyday lives constrained for decades by the presence of security forces. Neither side could claim victory by the 1990s, when peace talks began. In 1998, the Belfast/ Good Friday Agreement was signed. Founded upon a principal of compromise and parity, the agreement successfully facilitated the management of conflict, but reified rather than challenged division. The consociational model that underpins the peace process (Coakley 2009) is structured around maintaining a balance of power between the two communities, thus institutionalizing difference.

\section{Conclusion}

The island of Ireland in the early 21 st century continues to grapple with the legacies of the sectarian divide that was firmly codified in the 20th century and ultimately marked by the bloodshed and violence of the Troubles. But rather than presuming that this divide arose fully formed in the 16th and early 17 th century and remained fixed and static for the next 500 years, it would be much better to focus on the actual lived experiences of people in the past and the manner in which they negotiated political, economic, and religious change within a broader framework of nascent capitalism and its inherent inequalities. People in the past were equally capable of holding onto contradictory ideas and being directionless in the face of uncertainty. The desire to reduce past histories, such as that of plantation, to black-and-white caricature in order to justify and reify contemporary division does a considerable disservice to those who likely understood their lives in very different terms. Plantation-era sites contain within them evidence for a more complicated past, revealing the intertwined nature of the Gaelic world with that of the incoming plantersa world where religion was clearly a significant factor, but not necessarily the most important factor in terms of governing daily relations in a colonial setting rife with contradiction and uncertainty.

In the present, seemingly one-sided sites, such as Doddington's plantation manor at Dungiven, can serve as spaces for contemporary discourse and a reimagining of the past. For Northern Ireland in particular, engaging across community groups in a process of mutual discovery of shared histories confounds the simplicity of traditional colonial readings of the Irish past that pit Protestants against Catholics (Horning and Breen 2018; Horning 2019a, 2019b), holding promise for a future where all those who call the island of Ireland home can acknowledge the intertwined nature of past lives - lives such as those of the unnamed priest and the minister encountered by William Lithgow in the early 17th century. Ireland today, like Ireland yesterday, is constantly engaged in formulating new identities and understandings of itself; understandings wrought through global connections as much as local continuities. At this present moment, people in Ireland, north and south, of all faiths and no faiths, find themselves not just confounding the process of Brexit, but rethinking a present and a future where, for many, being European is increasingly seen as more important than any other aspect of identity.

\section{Declarations}

Conflict of Interest Statement The author declares that she has no conflict of interest.

Open Access This article is licensed under a Creative Commons Attribution 4.0 International License, which permits use, sharing, adaptation, distribution and reproduction in any medium or format, as long as you give appropriate credit to the original author(s) and the source, provide a link to the Creative Commons licence, and indicate if changes were made. The images or other third party material in this article are included in the article's Creative Commons licence, unless indicated otherwise in a credit line to the material. If material is not included in the article's Creative Commons licence and your intended use is not permitted by statutory regulation or exceeds the permitted use, you will need to obtain permission directly from the copyright holder. To view a copy of this licence, visit http://creativecommons.org/licenses/by/4.0/. 


\section{References}

Allison, Christopher M. B..

2016 Jamestown's Relics: Sacred Presence in the English New World. Conversations: An Online Journal of the Center for the Study of Material and Visual Cultures of Religion. Conversations, Essay, MAVCOR: Center for the Study of Material and Visual Cultures of Religion <https://mavcor.yale .edu/conversations/essays/jamestown-s-relics-sacred -presence-english-new-world>. Accessed 8 April 2021.

Armstrong, Robert

2019 Planting Protestantism in Urban Ulster. In Society and Administration in Ulster's Plantation Towns, Brendan Scott, editor, pp. 167-188. Four Courts Press, Dublin, Ireland.

Barnard, Toby C.

2004 The Kingdom of Ireland, 1641-1760. Palgrave Macmillan, Basingstoke, UK.

Bodley, Josias

1904 A Visit to Lecale. In Illustrations of Irish History and Topography, Mainly of the Seventeenth Century, C. Litton Falkiner, editor, pp. 326-344. Longmans, Green, and Co., London, UK.

Bradshaw, Brendan

1974 The Dissolution of the Religious Orders in Ireland under Henry VIII. Cambridge University Press, Cambridge, UK.

Brannon, Nick F.

1985 Archaeological Excavations at Dungiven Priory and Bawn. Benbradagh 15:15-18.

Brannon, Nick F., and Brooke Blades

1980 Dungiven Bawn Re-Edified. Ulster Journal of Archaeology 43:91-96.

Breen, Colin

2012a Dunluce Castle: History and Archaeology. Four Courts Press, Dublin, Ireland.

Breen, Colin

2012b Randal MacDonnell and Early Seventeenth-Century Settlement in Northeast Ulster 1603-30. In The Plantation of Ulster: Ideology and Practice, M. Ó Siochrú and E. Ó Ciardha, editors, pp. 143-157. Manchester University Press, Manchester, UK.

Byrne, Matthew J. (translator)

1903 Ireland under Elizabeth. Chapters towards a History of Ireland in the Reign of Elizabeth. Being a Portion of the History of Catholic Ireland by Don Philip O'Sullivan Beare. Sealy, Bryers \& Walker, Dublin, Ireland.

Carey, Vincent, and Ute Lotz-Heumann (editors)

2005 Taking Sides? Colonial and Confessional Mentalités in Early Modern Ireland. Four Courts Press, Dublin, Ireland.

Cherry, Jonathan

2019 'Lanterns of Civility': Ulster's Plantation Towns: Planning, Development and Urban Form, 1609-30. In Society and Administration in Ulster's Plantation Towns, Brendan Scott, editor, pp. 20-35. Four Courts Press, Dublin, Ireland.
Clendenning, Kieran

2004 The Brownlow Family and the Development of the Town of Lurgan in the Seventeenth Century: English Origin and the Ulster Plantation, Part 1. Seanchas Armhacha 20(1):100-123.

Coakley, John

2009 Implementing Consociation in Northern Ireland. In Consociational Theory: McGarry and O'Leary and the Northern Ireland Conflict, R. Taylor, editor, pp. 122-145. Routledge, London, UK.

Cochran Anderson, Jennifer Kay

2012 Wooden Devotional Sculpture in Ireland 1100-1800. Doctoral dissertation, Department of Art History, Pennsylvania State University, State College. University Microfilms International, Ann Arbor, MI.

Connolly, Sean

2008 Divided Kingdom: Ireland 1630-1800. Oxford University Press, Oxford, UK.

Cotter, Eamonn

2006 Architectural Change and the Parish Church in PostReformation Cork. In The Parish in Medieval and Early Modern Ireland, Elizabeth FitzPatrick and Raymond Gillespie, editors, pp. 242-265. Four Courts Press, Dublin, Ireland.

Cullen, Liam M.

1974 Population Trends in Seventeenth-Century Ireland. Economic and Social Review 6(2):149-165.

Curl, James Stephens

1986 The Londonderry Plantation. Phillimore, London, UK.

de Rochefort, Albert Jouvin

1672 Description of England and Ireland after the Restoration, C. Litton Falkiner, translator. CELT: The Corpus of Electronic Texts <https://celt.ucc.ie/ published/T100075/>. Accessed 2 June 2021.

Dickson, David

2005 Old World Colony: Cork and South Munster 1630 1830. University of Wisconsin Press, Madison.

Dobbs, Richard

1873 A Briefe Description of the County of Antrim, Begun on the 3rd of May, 1683. In An Historical Account of the Macdonnells of Antrim, George Hill, author, Appendix 2, pp. 377-389. Archer and Sons, Belfast, UK.

Donnelly, Colm

2005 The I.H.S. Monogram as a Symbol of Catholic Resistance in Seventeenth-Century Ireland. International Journal of Historical Archaeology 9(1):37-42.

Donnelly, Colm, and Eileen Murphy

2008 The Origins of Cilliní in Ireland. In Deviant Burial in the Archaeological Record, Eileen Murphy, editor, pp. 191-223. Oxbow Press, Oxford, UK.

Donnelly, Seamus, Colm Donnelly, and Eileen Murphy

1999 The Forgotten Dead: The Cilliní and Disused Burial Grounds of Ballintoy, County Antrim. Ulster Journal of Archaeology, 3rd ser., 58:109-113.

Doyle, David Noel

1981 Ireland, Irishmen, and Revolutionary America, 1760 1820. Mercier Press, Dublin, Ireland. 
Edwards, David

2005 A Haven of Popery: English Catholic Migration to Ireland in the Age of Plantations. In The Origins of Sectarianism in Early Modern Ireland, Alan Ford and John McCafferty, editors, pp. 95-126. Cambridge University Press, Cambridge, UK.

Ford, Alan

2005 Living Together, Living Apart: Sectarianism in Early Modern Ireland. In The Origins of Sectarianism in Early Modern Ireland, Alan Ford and John McCafferty, editors, pp. 1-23. Cambridge University Press, Cambridge, UK.

Gillespie, Raymond

1997 Devoted People, Belief, and Religion in Early Modern Ireland. Manchester University Press, Manchester, UK.

Graham, Brian

1994 The Search for the 'Common Ground': Estyn Evans' Ireland. Transactions of the British Institute of Geographers 19(2):183-201.

Gwynn, Aubrey, and Richard Neville Hadcock

1970 Medieval Religious Houses Ireland. Longman, London, UK.

Hamlin, Ann, and Nick Brannon

2003 Northern Ireland: The Afterlife of Monastic Buildings. In The Archaeology of Reformation 1480-1580, David Gaimster and Roberta Gilchrist, editors, pp. 252-266. Maney, Leeds, UK.

Heffernan, David

2015 Reconstructing the Estate of Richard Boyle, First Earl of Cork. History Ireland 23(2):18-20.

Heffernan, David

2018 Theory and Practice in the Munster Plantation: The Estates of Richard Boyle, First Earl of Cork, 16021643. In The Colonial World of Richard Boyle, First Earl of Cork, David Edwards and Colin Rynne, editors, pp. 43-63. Four Courts Press, Dublin, Ireland.

Hill, George

1873 An Historical Account of the Macdonnells of Antrim. Archer and Sons, Belfast, UK.

Hill, George (editor)

1869 The Montgomery Manuscripts (1603-1706). James Cleeland and Thomas Dargan, Belfast, UK.

Horning, Audrey

2009 'The Root of All Vice and Bestiality': Exploring the Cultural Role of the Alehouse in the Ulster Plantation. In Plantation Ireland, J. Lyttleton and C. Rynne, editors, pp. 113-131. Four Courts Press, Dublin, Ireland.

Horning, Audrey

2013 Ireland in the Virginian Sea: Colonialism in the British Atlantic. University of North Carolina Press, Chapel Hill.

Horning, Audrey

2018 Minding the Gaps: Exploring the Intersection of Political Economy, Colonial Ideologies, and Cultural Practice in Early Modern Ireland. PostMedieval Archaeology 52(1):4-20.

Horning, Audrey

2019a Collaboration, Collaborators, and Conflict:
Archaeology and Peacebuilding in Northern Ireland. Archaeologies 15(3):444-465.

Horning, Audrey

2019b Ethics, Empirical Honesty, and Listening for the Future: Embedding an Archaeology of Listening in Conflict Transformation. In Archaeologies of Listening, Peter Schmidt and Alice Kehoe, editors, pp. 202-223. University Press of Florida, Gainesville.

Horning, Audrey, and Colin Breen

2018 In the Aftermath of Violence: Heritage and Conflict Transformation in Northern Ireland. In Post-Conflict Archaeology and Cultural Heritage: Rebuilding Knowledge, Memory and Community from WarDamaged Material Culture, Paul Newsom and Ruth Young, editors, pp. 177-194. Routledge, London, UK.

Hunter, Robert

2011 Strabane Barony during the Ulster Plantation, 16071641. Ulster Historical Foundation, Belfast, UK.

Lacy, Brian

1983 Archaeological Survey of County Donegal. Donegal County Council, Lifford, Ireland.

Lennon, Colm

2019 Catholicism and the Ulster Plantation Towns. In Society and Administration in Ulster's Plantation Towns, Brendan Scott, editor, pp. 158-166. Four Courts Press, Dublin, Ireland.

Lindsay, Thomas Somerville

1914 Bishop Bedell. Irish Church Quarterly 7(27):223235.

Lithgow William

1974 The Rare Adventures and Painful Peregrinations of William Lithgow, Gilbert Phelps, editor. Folio Society, London, UK.

Loeber, Rolf

1991 The Geography and Practice of English Colonization in Ireland from 1534-1609. Group for the Study of Irish Historical Settlement, Dublin, Ireland.

Loeber, Rolf, and Magda Stouthammer-Loeber

2006 Kildare Hall, the Countess of Kildare's Patronage of the Jesuits, and the Liturgical Setting of Catholic Worship in Early Seventeenth-Century Dublin. In The Parish in Medieval and Early Modern Ireland, Elizabeth FitzPatrick and Raymond Gillespie, editors, pp. 242-265. Four Courts Press, Dublin, Ireland.

Logue, Paul

2016 A Reinterpretation of the Archaeology of the Nine Years' War in Ulster from a Cultural Perspective. Doctoral dissertation, Department of Archaeology and Palaeoecology, Queen's University Belfast, Belfast, UK.

Logue, Ruth, and Sarah Gormley

2007 Excavations at Saint Elizabeth's Church, Church Quarter, Dundonald, County Down. Queen's University Belfast, Centre for Archaeological Fieldwork, Data Structure Report 52. Belfast, UK.

Lysaght, Patricia

1997 Caoineadh os Cionn Coirp: The Lament for the Dead in Ireland. Folklore 108:65-83. 
Lyttleton, James

2008 Anglican Church Architecture in SeventeenthCentury Offaly. Journal of the Royal Society of Antiquaries of Ireland 138:80-104.

Lyttleton, James

2017 The Manor Houses of the First Lord Baltimore in an Atlantic World. Post-Medieval Archaeology 51(1): 43-61.

MacCarthy-Morrogh, Michael

1986 The Munster Plantation: English Migration to Southern Ireland 1583-1641. Clarendon Press, Oxford, UK.

MacCuarta, Brian

2016 Scots Catholics in Ulster, 1603-1641. In The Scots in Early Stuart Ireland, David Edwards and Simon Egan, editors, pp. 141-168. Manchester University Press, Manchester, UK.

MacCuarta, Brian (editor)

1993 Ulster 1641: Aspects of the Rising. Queen's University Belfast, Institute of Irish Studies, Belfast, UK.

MacDonnell, Hector

1992 A Seventeenth Century Inventory from Dunluce Castle, County Antrim. Journal of the Royal Society of Antiquaries of Ireland 122:109-127.

Mahaffy, Robert Pentland (editor)

1900 Calendar of State Papers Relating to Ireland of the Reign of Charles I, 1625-1632. Lord's Commissioners of Her Majesty's Treasury, London, UK.

McCormick, Finbar

2007 Reformation, Privatisation and the Rise of the Headstone. In The Post-Medieval Archaeology of Ireland 1550-1850, Audrey Horning, Ruairí Ó Baoill, Colm Donnelly, and Paul Logue, editors, pp. 355-370. Wordwell, Bray, Ireland.

McCormick, Finbar

2009 Struell Wells: Pagan Past and Christian Present. Journal of the Royal Society of Antiquaries of Ireland 139:45-62.

McGarry, John, and Brendan O'Leary

2000 Explaining Northern Ireland: Broken Images. Blackwell, Oxford, UK

McKenzie, Catriona, and Eileen Murphy

2018 Life and Death in Medieval Gaelic Ireland: The Skeletons from Ballyhanna, Co. Donegal. Four Courts Press, Dublin, Ireland.

McSkimin, Samuel

1909 The History and Antiquities of the County of the Town of Carrickfergus. McCrum, Belfast, UK.

Moody, Theodore W.

1939 The Londonderry Plantation, 1608-41. William Mullan and Son, Belfast, UK.

Moss, Rachel

2011 Continuity and Change: The Material Setting of Public Worship in the Sixteenth-Century Pale. In Dublin and the Pale in the Renaissance, 15401660, Michael Potterton and Thomas Herron, editors, pp. 182-206. Four Courts Press, Dublin, Ireland.

Mytum, Harold

2006 Popular Attitudes to Memory, the Body, and Social Identity: The Rise of Popular Commemoration in
Britain, Ireland and New England. Post-Medieval Archaeology 40(1):96-110.

Mytum, Harold

2009 Scotland, Ireland and America: The Construction of Identities through Mortuary Monuments by Ulster Scots in the Seventeenth and Eighteenth Centuries. In Ireland and Britain in the Atlantic World, Audrey Horning and Nick Brannon, editor, pp. 235-252. Wordwell, Dublin, Ireland.

O’Neill, James

2017 The Nine Years War, 1593-1603: O'Neill, Mountjoy, and the Military Revolution. Four Courts Press, Dublin, Ireland.

O Súilleabháin, Seán

1967 Irish Wake Amusements. Mercier, Dublin, Ireland.

Parno, Travis

2006 A Case for Catholicism: A Contextual Study of Religious Small Finds from Historic James Fort, Jamestown, Virginia. Undergraduate honors thesis, Department of Anthropology, College of William and Mary, Williamsburg, VA.

Penn, William

1952 My Irish Journal 1669-1670, Isabel Grubb, editor. Longmans, Green and Company, London, UK.

Roulston, William

2019 Strabane: A Plantation Town and Its Hamilton Landlords. In Society and Administration in Ulster's Plantation Towns, Brendan Scott, editor, pp. 82-98. Four Courts Press, Dublin, Ireland.

Russell, Charles W., and John P. Prendergast (editors)

1880 Calendar of State Papers relating to Ireland, of the Reign of James I, 1615-1625: Preserved in the Great Britain Public Record Office. Longman and Sons, London, UK.

Scott, Brendan

2005 The Dissolution of the Religious Houses in the Tudor Diocese of Meathe. Archivium Hibernica 59:260 276.

Scott, Brendan

2012 Accusations against Murtagh King, 1638. Archivium Hibernica 65:76-81.

Scott, Brendan

2013 The 1622 Royal Visitation of the Church of Ireland in Ulster. In Plantation: Aspects of SeventeenthCentury Society, Brendan Scott and John Dooher, editors, pp. 55-68. Ulster Historical Foundation, Belfast, UK.

Sutton, Malcolm

2001 Malcolm Sutton: An Index of Deaths from the Conflict in Ireland. Ulster University: CAIN $<$ http://cain.ulst.ac.uk/sutton/>. Accessed 12 April 2021.

Tait, Clodagh

2001 Colonising Memory: Manipulations of Death, Burial and Commemoration in the Career of Richard Boyle, First Earl of Cork (1566-1643). Proceedings of the Royal Irish Academy. Section C: Archaeology, Celtic Studies, History, Linguistics, Literature 101C(4): 107-134. 
Tait, Clodagh

2002 Death, Burial, and Commemoration in Ireland 15501650. Palgrave MacMillan, Basingstoke, UK.

Tait, Clodagh

2005 Using and Abusing the Dying and the Dead in Early Modern Ireland. History Ireland 13(1):16-20.

Tarlow, Sarah

2003 Reformation and Transformation: What Happened to Catholic Things in a Protestant World? In The Archaeology of Reformation 1480-1580, David Gaimster and Roberta Gilchrist, editors, pp. 108121. Oxbow Press, Oxford, UK.

Tarlow, Sarah

2011 Ritual, Belief and the Dead in Early Modern Britain and Ireland. Cambridge University Press, Cambridge, UK.

Tracey, Rachel, and Audrey Horning

2019 Ulster Plantation Towns: An Archaeology of Rhetoric and Reality. In Society and Administration in Ulster's
Plantation Towns, Brendan Scott, editor, pp. 6-19. Four Courts Press, Dublin, Ireland.

Walsh, Reginald

1917 A Memorial Presented to the King of Spain on Behalf of the Irish Catholics, A.D. 1619 Archivium Hibernicum 6:27-54.

Walsham, Alexandra

2010 Skeletons in the Cupboard: Relics after the English Reformation. Past and Present 206(S5):121-143.

Willmott, Hugh, and Alan Bryson

2013 Changing to Suit the Times: A Post-Dissolution History of Monk Bretton Priory, South Yorkshire. Post-Medieval Archaeology 47(1):136-163.

Publisher's Note Springer Nature remains neutral with regard to jurisdictional claims in published maps and institutional affiliations. 